\title{
Childminding in Ireland: attitudes towards professionalisation
}

\author{
Miriam O'Regan \\ Technological University Dublin, miriam.oregan@tudublin.ie \\ Ann Marie Halpenny \\ Technological University Dublin, Annmarie.Halpenny@tudublin.ie \\ Noirin Hayes \\ Technological University Dublin, noirin.hayes@tudublin.ie
}

Follow this and additional works at: https://arrow.tudublin.ie/aaschsslarts

Part of the Early Childhood Education Commons, and the Sociology Commons

\section{Recommended Citation}

O'Regan, M., Halpenny, A. \& Hayes, N. (2019). Childminding in Ireland: attitudes towards professionalisation, European Early Childhood Education Research Journal, vol. 27, no. 6, pg. 757-775. doi:10.1080/1350293X.2019.1678716

This Article is brought to you for free and open access by the Social Sciences at ARROW@TU Dublin. It has been accepted for inclusion in Articles by an authorized administrator of ARROW@TU Dublin. For more information, please contact arrow.admin@tudublin.ie, aisling.coyne@tudublin.ie,gerard.connolly@tudublin.ie. Funder: Irish Research Council

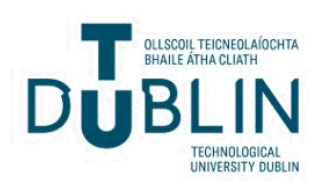




\section{Childminding in Ireland: attitudes towards professionalisation}

\section{Miriam O'Regan, Ann Marie Halpenny \& Nóirín Hayes}

To cite this article: Miriam O'Regan, Ann Marie Halpenny \& Nóirín Hayes (2019) Childminding in Ireland: attitudes towards professionalisation, European Early Childhood Education Research Journal, 27:6, 757-775, DOI: 10.1080/1350293X.2019.1678716

To link to this article: https://doi.org/10.1080/1350293X.2019.1678716

\section{Published online: 21 Oct 2019.}

Submit your article to this journal $\sqsubset$

Џll Article views: 452

Q View related articles $\asymp$

View Crossmark data ¿

Citing articles: 2 View citing articles $\square$ 


\title{
Childminding in Ireland: attitudes towards professionalisation
}

\author{
Miriam O'Regan (D) ${ }^{a}$, Ann Marie Halpenny ${ }^{b}$ and Nóirín Hayes ${ }^{c}$ \\ ${ }^{a}$ School of Languages, Law and Social Sciences, Technological University Dublin, Grangegorman, Dublin, \\ Ireland; 'School of Languages, Law and Social Sciences, Technological University Dublin, Grangegorman, \\ Dublin 7, Ireland; 'Professor Emerita, Technological University Dublin, and Visiting Professor, School of \\ Education, Trinity College Dublin
}

\begin{abstract}
In light of rapid changes in the early years sector in Ireland since 2000, questions arise about the professionalism of childminders (family day carers), the vast majority of whom are exempt from regulation. Fewer than $0.1 \%(<120)$ of childminders are registered with Tusla, the national regulator, despite the National Childminding Initiative, (NCMI) which has promoted professional, high quality childminding. To investigate current attitudes to NCMl's process of professionalisation (Brannen and Moss [2003]), among childminders and parents, a cross-sectional study was designed using a mixedmethod approach. Specifically an anonymous online survey was conducted with 325 participants, followed by a qualitative World Café forum for 40 members of Childminding Ireland, the national childminding body. Findings from both phases of research revealed many of these childminders were well-qualified and engaged, with a sense of professional identity, seeking a distinctive approach to support childminding. Moreover, both childminder and parent participants value the distinctive characteristics of childminding close relationships, a nurturing pedagogy, a rich, home environment - to a greater extent than markers of professionalism. These findings call for an innovative approach to childminding in Ireland, one that facilitates an organic development of agentic, professional childminding as part of a competent ECEC system.
\end{abstract}

\section{KEYWORDS}

Professionalisation; childminding (family daycare); competent system; Ireland

\section{Introduction}

A large body of literature highlights substantial and significant change and development within the childcare sector in Ireland, since the advent of the first National Childcare Strategy at the start of the twenty-first century (DJELR 2000; OECD 2004a; Hayes and Newman 2005; Hayes and Bradley 2009; Gallagher 2012; Wolfe, O'Donoghue-Hynes, and Hayes 2013; Neylon 2014; Govt. of Ireland 2019). Such developments were initially driven by labour market demands, with capital investment in facilities under two EU supported, government-funded programmes: the Equal Opportunities Childcare Programme (EOCP, 2000-2006) and the National Investment Childcare Programme (NICP, 2006-2013), both of which included a childminding strand: the National Childminding Initiative (NCMI).

CONTACT Miriam O'Regan D13128461@mytudublin.ie School of Languages, Law and Social Sciences, Technological University Dublin, Grangegorman, Dublin, Ireland (c) 2019 EECERA 
Change was furthered by the development of national frameworks for early years learning Síolta (CEDCE 2006) and Aistear (NCCA 2009), for all types of settings, including childminding.

In this rapidly evolving context, the professionalisation of the early years workforce in Ireland has been considered key to ensuring the provision of quality ECEC services, as it has internationally, with new standards, regulations and qualifications being introduced, promising professional status and rewards (Hargreaves 2000; Brannen and Moss 2003). This process of professionalisation has been much debated and contested amidst concerns that a techno-rationalist professionalism imposed from above is at odds with an autonomous, agentic professionalism from within (Osgood 2006, 2010; Moloney 2010; Peeters and Vandenbroeck 2011; Brock 2013; Lightfoot and Frost 2015; CampbellBarr 2018; Dyer 2018). This tension is also reflected in the CoRe report (2011), which conceives of professionalism in childcare on a spectrum from exclusive to inclusive (Lumsden 2010; Ortlipp, Arthur, and Woodrow 2011; Urban et al. 2011; Musatti, Picchio, and Mayer 2016; Peeters, Urban, and Vandenbroeck 2016). While Urban et al. advocate for a more democratic participatory model ... which includes parents, children, the wider community and, more generally, society (Urban et al. 2011, 99) unfolding within a competent system (Urban et al. 2011, 17), even this argument is still somewhat contested.

Similarly, recent discussions of the professionalisation of childminders also reveal fault lines of dissension. Some childminders embrace a child-centred, home-fromhome ethos, while others actively seek parity of esteem on the same terms as centrebased practitioners, with the same qualifications, as part of one overarching ECEC sector (Cresson, Delforge, and Lemaire 2012; Fagnani and Math 2012; Bauters and Vandenbroeck 2017; Vandenbroeck and Bauters 2017). Still others see themselves, as independent, self-employed service providers, rejecting technical performative professionalism imposed by regulation in favour of an autonomous agentic professionalism from within (Jones and Osgood 2007; O'Connell 2011; Ang, Brooker, and Stephen 2016). To analyse the current attitudes of childminders to professionalisation since NCMI, this research has explicitly drawn on the model proposed by Brannen and Moss which emphasises a process approach to professionalisation, beginning with a focus on rising levels of education and ultimately generating novel and innovative approaches to professionalisation.

Childminding remains under-researched in Ireland and internationally (Kontos 1994; Karlsson 1995; Mooney and Statham 2003; Jones and Osgood 2007; O'Connell 2011; Ang, Brooker, and Stephen 2016; Brooker 2016; Bauters and Vandenbroeck 2017), and its place within a competent system remains unclear. In Ireland also, little research has focussed either on childminding or its professionalisation (Daly 2010); even less so from the perspectives of stakeholders (Garrity and McGrath 2011). As the CoRe report summarises: In some parts of Europe (e.g. France and Belgium) they (childminders) constitute the largest part of the care and education workforce for the youngest children (from birth to the age of three), and few formal competences or qualifications are required. In many countries, they work in very difficult conditions, with limited educational support and low income ... In short, it is a largely undervalued workforce ... that deserves particular attention with regard to its professionalism (Urban et al. 2011, 14). 


\section{Theoretical framework: the process of professionalisation}

From 2002 to 2013, the National Childminding Initiative (NCMI) promoted the professionalisation of childminding in Ireland. One of the main drivers for this emphasis on professionalisation and greater regulation has been a concern for the quality of childminding services and the associated outcomes for children. In parallel with the ECEC sector as whole, this initiative was intended to stimulate the process of professionalisation in Irish childminding.

Different strands of NCMI were presented as the means of improving childminding quality. Firstly, by promoting training for childminding with a free 10-hour course, the Quality Awareness Programme for Childminders (QAP); secondly, by providing local support through dedicated Childminder Advisors, who offered home visits, and who were also tasked, thirdly, with developing local childminder networks. In addition, the fourth component in NCMI was financial: a tax relief to encourage childminders to engage in the formal economy, with social insurance benefits; and a childminder development grant aimed at enriching the home learning environment, which also promoted holding insurance for the childminding service (DCYA 2008; Daly 2010). Childminding Ireland was also funded under NCMI as the national childminding body to assist in the development of professional standards for members. This process of professionalisation held out the promise of rising levels of education leading to improved pay and conditions, and better career prospects, in line with the paradigm of professionalisation of care workers proposed by Brannen and Moss (2003), outlined in Figure 1. However, to date, there has been no national evaluation of the impact this NCMI, (and its discontinuation since 2013) has had on the attitudes of Irish childminders regarding professionalisation.

Yet childminding remains the most common form of paid childcare used in Ireland, with an estimated 35,000 childminders nationally - an estimate which has remained

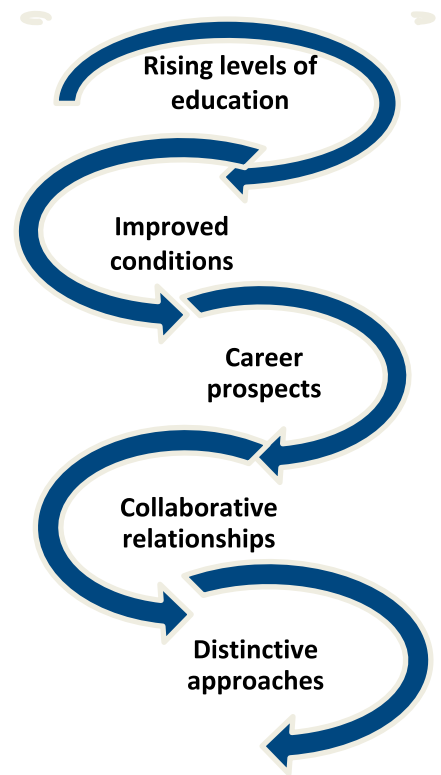

Figure 1. The Process of Professionalisation based on Brannen and Moss (2003). 
reasonably constant since the OECD review of childcare in Ireland in 2000 (Corrigan 2000; Goodbody Economic Consultants 2011; DCYA 2017; DCYA Working Group 2018). A childminder is the most used type of non-parental childcare for both preschool and primary school children with 27 hours and 16 hours per week respectively (Central Statistics Office 2017b). Apart from the free preschool years for children aged 3-4 years, childminders provide the largest proportion of paid childcare for children up to six years of age, according to the most recent data (Govt. of Ireland 2019), as well as the highest proportion of paid afterschool childcare for $7 \%$ of primary school children (DCYA 2017). According to the Irish Central Statistics Office, an estimated $10 \%$ of children in Ireland from infancy to 12 years of age receive childcare services from paid childminders /au pairs/nannies (Central Statistics Office 2017b).

However, there are fewer than 100 childminders registered with Tusla, the national regulator, as the vast majority of childminding services are exempt from regulation; furthermore, Childminding Ireland has only 700 members approximately. This means that as many as approximately 88,000 children under 12 years of age (Central Statistics Office 2017a) may attend a 'hidden' childminding setting in Ireland, one without any regulation or support. Despite repeated recommendations and calls for the regulation of childminding (Start Strong 2012; DCYA 2013; DCYA Working Group 2018), childminding still receives insufficient and inappropriate treatment in the most recent Early Years Services Regulations (DCYA 2016), with declining numbers of childminders coming forward to register as a consequence. Since the introduction of universal free preschool for children over three years of age in 2010, and the suspension of the National Childminding Initiative, it seems childminding has been systemically neglected, perhaps because it is even further from the 'school gate' than centre-based early years' practitioners (OECD 2006, 158), confirming Baker and Lynch's observation: In policy-making, employment and formal politics, carers and care recipients are not highly valued except at a rhetorical level $(2012,12)$.

Yet even though childminding is frequently perceived to be of lower status, (Davis et al. 2012; Tonyan 2015; Vandenbroeck and Bauters 2017) recent international research indicates the many, multi-faceted benefits associated with childminding. In addition to its potential as a type of family support, especially for vulnerable families, childminding offers a unique pedagogical approach to children's developmental and educational outcomes that is distinct from any other types of early years care (Fauth et al. 2011; Fauth, Owen, and Jelicic 2013; Shannon, Geraghty, and Molyneaux 2014; Ang, Brooker, and Stephen 2016; Brooker 2016). Recent research in Europe has highlighted the benefits of childminding for children. Smaller group size, such as in a childminder's, has been linked to higher process quality in childcare settings in Belgium (Laevers et al. 2016), and there are indications that younger children having childcare develop optimally within smaller and more intimate non-parental settings, with fewer peers and greater adult-child ratios than centre-based programmes (Melhuish 2016). Higher verbal ability has been associated with use of childminding, as has better emotional and behavioural self-regulation both in the Study of Early Education and Development in England (Otero and Melhuish 2015; Melhuish, Gardiner, and Morris 2017), and in Growing Up in Ireland reports (McGinnity, Russell, and Murray 2015; Russell, Kenny, and McGinnity 2016), notwithstanding the informal nature of childminding care in Ireland. 
The demand for quality, affordability and accessibility in early childhood services continues to increase (Plantenga et al. 2008; Lloyd and Penn 2012). In this context, the importance of exploring the inspiring practices of childminders opens up the possibility of generating new understandings of professionalism in light of the commonalities and differences of childminding providers in the professionalisation debate (O'Connell 2008; Page 2011; Dalli, Miller, and Urban 2012; Tonyan and Nuttall 2014; Lightfoot and Frost 2015; Vandenbroeck and Bauters 2017).

\section{Methodology}

\section{Research approach}

The focus of this research was first to explore attitudes towards the process professionalisation in Irish childminding, as promoted by NCMI, and second to gain a greater understanding of what childminders and parents understand by the term professionalism with reference to childminding in the Irish context. The central research question was: What constitutes a high quality, professional childminder in the opinion of childminders and parents? Firstly, the views were sought of both childminders and parents via an online survey in 2015, on existing childcare regulations, the national early years frameworks, and the effects of the support systems for childminders developed and withdrawn in the National Childminding Initiative. Secondly, in 2016, a World Café forum was used to consult with members of Childminding Ireland, the national professional body for childminders, as to how any future regulatory and support system could be developed that would be proportionate to both the childminders' home environment and the needs of the children in their care.

To investigate this, a cross-sectional study was designed using a mixed-method approach with both quantitative and qualitative components in a pragmatic paradigm (Creswell 2009; Fetters, Curry, and Creswell 2013; Denscombe 2014). Quantitative data were generated on attitudes towards professionalisation using an anonymous, self-completion survey, conducted online in May 2015 - an innovation necessitated by the 'hidden' nature of the vast majority of exempt childminders. In 2016, this was followed by a World Café forum, a variation on the focus group necessitated by the larger number of childminders expected at the annual general meeting of Childminding Ireland, the national professional childminding body with approximately 700 members. This format allowed for a less researcher directed conversational dynamic to develop as these professionalised childminders discussed the future of childminding in Ireland (Brown and Isaacs 2007; Brown, Homer, and Isaacs 2007; The World Café Community Foundation 2015).

\section{The online survey}

One of the challenges in conducting this research was the 'hidden' population involved, as childminders' exempt status means that the vast majority are private and unknown to formal agencies, historically operating in the black economy as a result (Heckathorn 1997; Higgins 1998). Consequently, an anonymous online survey was created to access the views of childminders and parents. Two questionnaires were developed, one for childminders and another for parents, both designed to assess the impact of all aspects of the National Childminding Initiative, as well as awareness of the Early Years Regulations, 
Aistear and Síolta, the national curriculum and quality frameworks, in addition to background questions on fees, qualifications and motivations for childminding or for using childminding. These two surveys were presented as one, with 105 questions in total, to allow for ease of presentation on social media. However, skip logic was applied so that parents or childminders were directed only to the questions relevant to them. A wide range of question types were used including rating scales, ranking, and open-ended questions allowing for textual responses (Denscombe 2009; Survey Monkey 2009; Fetters, Curry, and Creswell 2013; Bryman 2016; Malthus 2017).

The anonymous online survey was sent out by email to members of Childminding Ireland and Childcare Committee childminding networks, with a request to pass it on to parents in their service. To allow for as large a response rate as possible, the survey link was also placed, as a group member, on Facebook pages created by and for childminders and parents, to create a form of respondent-driven sampling (Brickman-Bhutta 2012; Baltar and Brunet 2012). This strategy was quite successful in reaching a large number of stakeholders in a self-selecting, non-probability sample. In total, 450 respondents from twenty-three of the twenty-six counties took the online survey: $63 \%$ childminders and $37 \%$ parents, with a completion rate of $63 \%$, that is 325 surveys. On the whole, this online strategy also was relatively effective in reaching 'hidden' childminders: Over $79 \%$ were exempt childminders, and nearly $35 \%$ of the sample had had no contact whatsoever with any government body. Nonetheless, nearly $20 \%$ of the sample were or had been registered childminders (vs. $0.1 \%$ nationally), and nearly $60 \%$ were or had been members of Childminding Ireland, so one limitation of the present study is that it may be reflecting primarily the views of those childminders who are better qualified and, therefore, more confident about coming forward to participate.

\section{A World Café: the childminding community Café forum}

The World Café method of community discussion originated from a fresh approach to organisational change known as Appreciative Inquiry, referring to a research perspective that goes beyond mere problem solving to fostering innovations collaboratively (Cooperrider and Srivastva 1987). The World Café process arose to facilitate 'conversations that matter' in a hospitable environment conducive to real exchanges, particularly effective for larger groups (Brown and Isaacs 2007; Steier, Brown, and da Silva 2015). Unlike a focus group, which is researcher directed, a World Café allows research participants to explore questions relevant to them in a series of conversations with three or more revolving small groups, carrying the learning from each table forward to the next, with only the host staying in place. At the Childminding Community Café, conducted with members of the national professional association, Childminding Ireland, 40 childminder members engaged in thinking about what childminding could be in an ideal world in order to generate a collaborative discussion on the Future of Childminding. This group represented the professionalised subset of Irish childminders: there are only 700 members in Childminding Ireland, while there are an estimated 35,000 childminders in the country.

\section{Research ethics}

Key aspects of ethical considerations were adhered to in the present study. The study was approved by the Research Ethics Committee in Technological University Dublin. 
Participants had access to comprehensive information regarding the implications of their participation in the study (Creswell 2009; Bryman 2016), the right not only to agree to participate in the research but also to decide on which information to provide as part of the research and to withdraw from the research at any time. Confidentiality and anonymity was ensured and the research was fully compliant with all legal requirements regarding the collection, storage, processing and analysis of data. Any results will be put into the public domain on an anonymised basis with a view to transparency, scrutiny and peer review.

\section{Key findings}

\section{Many childminders hold national childcare qualifications}

A key finding emerging from the study, as illustrated in Figure 2, was the surprisingly high percentage of childminders who held accredited awards from Quality \& Qualifications Ireland (QQI) at level 5 or higher, making participants eligible to work in a centre-based childcare setting. Even though this is not a statutory requirement, 71 childminders held QQI level 5, 45 held QQI level 6, and 13 held degrees in ECEC. In addition, 84 participants had completed the free government sponsored training for childminders, the Quality Awareness Programme (QAP), which was unaccredited. Special training is required in most regulated systems across Europe, in France, for example, the course takes 160 hours over two years; the QAP was 10 hours over 5 weeks.

Consistent with Brannen and Moss (2003) process of professionalisation paradigm, Irish childminders' educational level is rising, despite the lack of official incentive or recognition for the exempt majority. Only qualified, regulated childminders in Ireland can

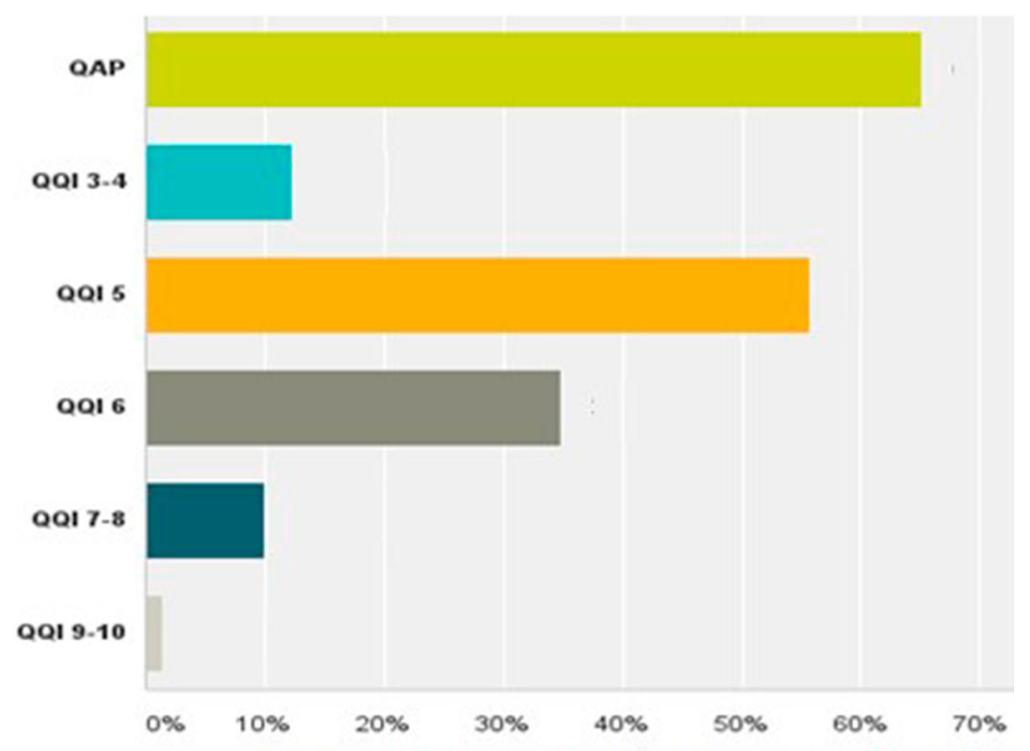

Figure 2. Childminders' level of ECEC education. 
provide the Free Preschool Scheme or the National Childcare Scheme. However, the incentive of participation in such schemes has so far failed to persuade the majority of Irish childminders to register under the current Early Years regulations (Department of Children \& Youth Affairs 2016; Moloney 2016).

\section{Childminders have yet to experience improved conditions}

In light of the promise of professionalisation leading to improved conditions, (Hargreaves 2000; Brannen and Moss 2003), childminders are led to expect that gaining qualifications will improve their earnings and conditions of work, such as holidays and sick leave. However, these expectations were not borne out in the present study findings. On the contrary, of those who answered the questions on fees (138), over $49 \%$ were only earning between $€ 3-4.99$ per hour per child, while of the 105 childminders with childcare qualifications who responded to that question, slightly more (51\%) were in the same category. Overall, $60 \%$ of all childminders were earning less than $€ 5$ per hour per child, a figure which has remained virtually unchanged since 2004, as annual surveys of childcare costs confirm (Feeley 2012).

Similarly, there was no discernible relationship between higher levels of qualifications and better holidays or holiday pay. Of all respondents to this question, over $57 \%$ (81) get no paid holiday, while over $58 \%$ (45) of those who hold qualifications also get no paid holidays whatsoever. Only 56 respondents were paid for bank holidays, 22 were paid at Christmas, and 17 received summer holiday pay. Moreover, no childminder made any reference to payment while off sick (Figure 3).

\section{Childminders identify as independent professional service providers}

Yet, despite this, some childminders in their textual comments clearly articulated their role as self-employed business owners, consistent with the entrepreneurial concepts promoted by NCMI in parallel with childminding developments in England (DCYA 2008; Osgood 2004; Bond and Kersey 2001). Over 42\% (80) had received the childminder development grant at some point, one of the financial provisions of the NCMI still partially in operation,

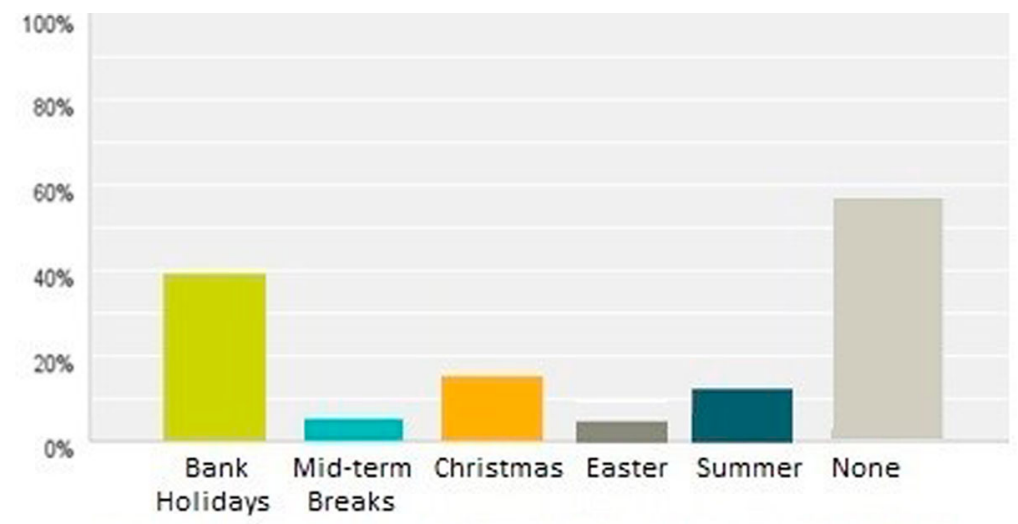

Figure 3. Childminders' Paid Holidays. 


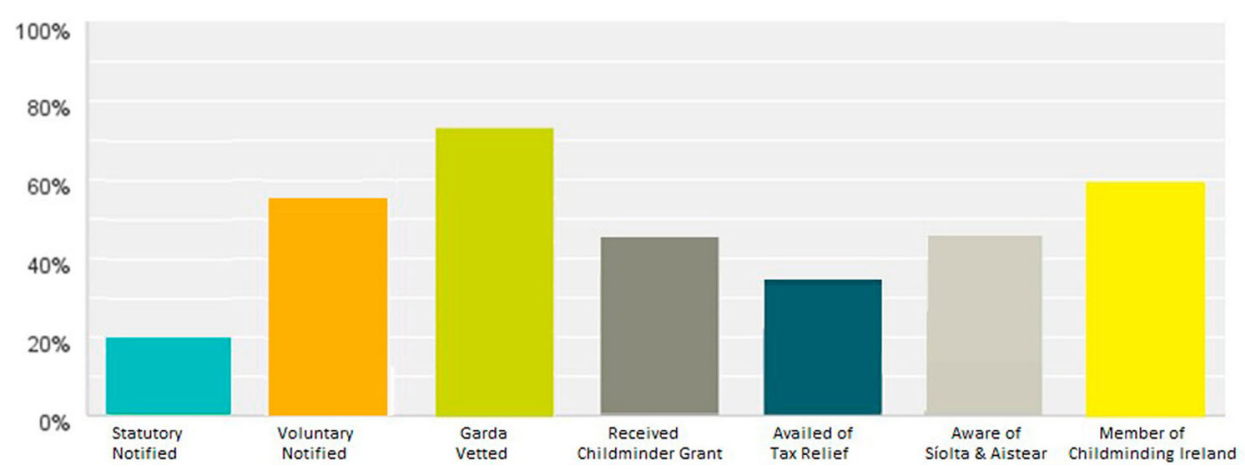

Figure 4. Childminders' Markers of Professionalism.

but only $35 \%$ (63) of childminder respondents had availed of the tax relief, as part of the formal economy (see Figure 4). Commentary revealed that a small number were satisfied with the tax relief because it allows them to pay social insurance towards maternity leave or a state pension. Many commentators found it too limiting: it was only available for income up to $€ 15,000$ per annum to those who minded three or fewer children. In some parts of Ireland a childminder could be caring for six children, but still earn less than $€ 15,000$ per annum, while in other parts, childminders reduced their numbers to ensure they did not earn above the threshold and become liable for tax on all income earned.

Nonetheless, despite the lack of financial reward, many childminders valued their role as independent service providers in a self-directed career in childcare, availing of existing supports and enjoying high levels of personal agency, similar to findings in international research (Tonyan 2017, 2012; Tonyan, Paulsell, and Shivers 2017). Figure 4 demonstrates that nearly $20 \%$ (36) of childminder respondents were or had been statutory notified in the regulated system under the Health Service Executive, the regulatory body prior to Tusla. Nearly 55\% (99) had been voluntarily notified to local Childminding Advisory Services in a form of self-regulation. Nearly 60\% (107) were members of the national professional body for childminding, Childminding Ireland, which supports childminders' self-professionalising process, by promoting practices such as holding insurance, as a requirement for membership. Further, over 73\% (132) held Garda vetting, even though it is not mandatory for exempt childminders, despite the fact that they work alone with children unsupervised (Acts of the Oireachtas 2012-2016). In addition, while there is no obligation on exempt childminders to adopt or reference curriculum frameworks within the ECEC sector, over $45 \%$ childminders in the study were aware of the national childcare frameworks: Síolta $(=82)$ (CECDE 2006) and Aistear (=86) (NCCA 2009), with over 50\% (91) of childminder respondents indicating that they found these frameworks helpful or very helpful for their practice.

\section{Respondents value the distinctive characteristics of childminding}

Childminders and parents both value key distinctive characteristics of childminding in the Irish context, with a high degree of consensus as seen in the averaged rankings in Figure 5. 


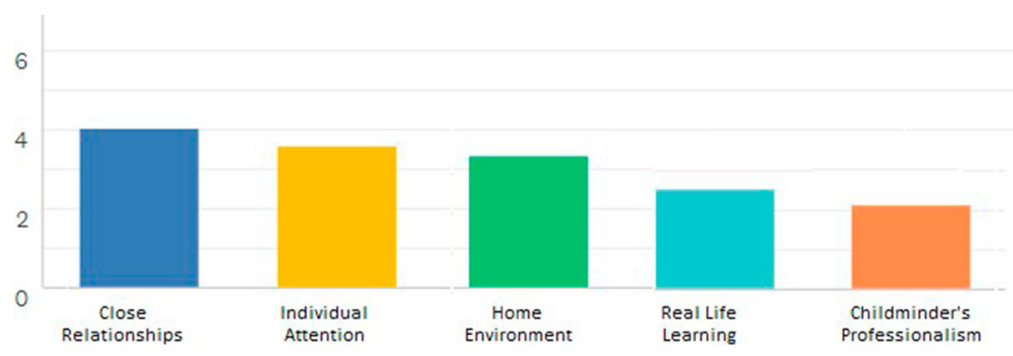

Figure 5. Ranking of Characteristics of Childminding.

When asked to place five categories in relative importance to one another, (i.e. the home environment, the close relationships, the individualised care and attention for the child, real-life learning, and professionalism) a very clear consensus emerged about what both childminders and parents consider makes a high-quality childminding service. Both childminder (141) and parent (20) respondents to this question gave first ranking to the relationships between childminder and child/ren as being most important. Individualised care and attention was ranked second place, and both also agreed on the third-place ranking for the home environment. Both childminders and parents ranked real-life learning in fourth place in order of priority.

Surprisingly, professionalism - defined as using contracts and policies, and holding qualifications and insurance, etc. - was considered least important by both parents and childminders - 76 childminders ranked it as least important as did 12 parents. Given the positive attitudes in relation to qualifications, and to their role as independent service providers, this was a striking and paradoxical finding. Participants very clearly made a distinction between qualifications and quality practice which they prioritise in terms of professionalising childminding, in contrast to the narrower definition of professionalism, defined as using contracts and policies/insurance and so on, which bespeaks a much more 'top-down' bureaucratic approach.

\section{Childminders seek a distinctive approach to childminding}

In order to explore these findings further, the World Café forum on the Future of Childminding was organised as the part of the annual general meeting of Childminding Ireland, whose 700 members are highly motivated childminders, who are a self-professionalising body, with a collaborative approach to raising members' standards. After a short presentation of survey findings, 40 childminders broke into eight rotating groups, out of which several distinct ideas emerged in response to the three core questions considered in the Café (1) What type of regulations should be in place for childminding at its best into the future? (2) What type of training should childminders get to support childminding at its best in future? (3) What kind of supports should there be nationally/locally to support childminding at its best?

First, apart from relative childcare, childminders called for all paid, home-based childminders to be regulated, but under distinctive, proportionate childminding regulations, which do not focus on policies and paperwork. The single most frequently mentioned idea was that regulations and inspection for childminders would have to be different 
from the crèche regime; the inspectorate would have to be mindful of and attentive to the fact that childminders worked within home settings and needed procedures based on regulations for a home, not centre based'. Indeed, taken as a whole, participants advocated a distinct approach to the inspection of childminding which placed emphasis on themed, childcentred, observational, with a grading system rather than compliant/non-compliant, using self-evaluations, and inspection against standards versus regulations. Above all, regulations would have to be 'realistic and achievable for childminders'. This was a clear expression of a desire for more autonomous, agentic professionalism and a bottom-up approach to its development.

Second, childminders believed that national accredited components and awards at QQI level 5 and 6 should be created specifically for childminding ECEC. In particular, in addition to core childcare education, they felt education in business skills for childminding would be very useful. Consistent with Brannen and Moss (2003) process of professionalisation paradigm, these childminders are seeking a distinctive approach to their field, one which they should determine as a profession.

Thirdly, while some participants thought that QQI level 5 should be mandatory for childminders in line with the ECEC sector as a whole, all were interested in either funded or subsidised childminder education, which would be flexible and also offer incentives to progress to higher levels, as well as access to continued professional training.

Fourth, childminders sought dedicated, local support workers for the development of childminding: 'people who specialise in childminding as a statutory post - outside of a regulatory inspection team' to help with training, setting up and maintaining services. This dedicated person could be available for home visits, as well as phone calls around childminding issues. Local childminding development workers were part of the National Childminding Initiative, and many childminders expressed their feelings of loss when that support became unavailable.

Fifth, they repeatedly called for local networks for childminders to be created, where they could meet with or without children. These peer support groups could feed into a national support forum, and support peer mentoring schemes so that more experienced local childminders could coach and mentor those in need of support.

Sixth, childminders suggested that a national register of childminders should be made available in a database accessible to the general public to provide transparency to the childminding system, along with a national media campaign advertising the benefits of childminding, and a national helpline to field an queries around schemes, training or regulations.

Finally, once registered under specific, proportionate, childminding regulations, childminders considered that trained childminders should be allowed to provide whatever government-funded childcare schemes are in place. Once the requirements were considered appropriate to home-based childminding, focussed on the child, not policies, paperwork and property, they felt that inclusion in publically funded childcare schemes would be a major incentive to engage with regulatory and quality improvement schemes (Porter, Bromer, and Moodie 2011; Letablier and Fagnani 2009; The Scottish Government 2017). Again this fits in well with a clear distinction in terms of professionalism in childminding being understood as implicit in high quality childminding services. 


\section{Discussion}

The present study suggests progress on four of the five components in the process of professionalisation as promoted under NCMI and described by Brannen and Moss (2003). Childminders in the study have rising levels of education, they are more likely to embrace childminding as a career, they enjoy collaborative relationships within Childminding Ireland, and they value their distinctive practice as childminders.

However, despite the enthusiasm and commitment reflected in the narratives of childminders in the present study, a significant challenge identified was the high cost of childcare for parents, and the relatively low earnings of childminders, despite the relatively high standard of qualifications of these childminders. In this domain, the promise of professionalisation is not being realised: more highly qualified childminders in the present survey were not experiencing improved conditions of work.

Nonetheless, after a decade of investment under the National Childminding Initiative, professionalised childminders, such as the members of Childminding Ireland, seek visibility in a transparent system as part of a national ECEC infrastructure, such as in France, the Netherlands or Belgium (Letablier and Fagnani 2009; Boogaard, Bollen, and Dikkers 2013; Laevers et al. 2016). As such, they advocate for specific childminding qualifications in ECEC, staffed local networks; and proportionate childminding regulations, once accompanied by supports. Participants prioritised an approach to professionalism that was more aligned to an autonomous, agentic model rather than an overly prescriptive, imposed model (Osgood 2006; Jones and Osgood 2007).

Moreover, this must be considered in the light of a significant caveat: professionalisation cannot compromise the essential nature of childminding, but instead should be derived from its distinctive characteristics in a bottom-up, organic manner. Childminders are unwilling to sacrifice their autonomy to an insensitive regulatory regime, which they consider more a hindrance than a help, as evidenced by declining numbers of registrations with Tusla. Nor are they prepared to be reduced to 'mini-crèches' or a performative version of childminding; instead they seek to construct a more organic, autonomous, agentic professionalisation from within (Jones and Osgood 2007; O'Connell 2011, 2008; Lightfoot and Frost 2015; Brooker 2016). Childminders in this study seek to have their distinctive, professional approach to childcare recognised for what it is, rather than be subject to an imposed professionalisation agenda, which many fear would be more controlling than empowering (Campbell-Barr 2018; Dyer 2018).

The caution of Irish childminders is warranted: much depends on the type of regulations, education and supports in place. Since 2000, in England, childminders have had access to higher ECEC qualifications (Nutbrown 2012; Simon, Owen, and Hollingworth 2015; Brooker 2016), regulation and inspection under a common framework, and access to provision of government-funded schemes. Nevertheless, the number of registered childminders in England declined from 103,000 in 1996 to 43,500 by 2016 (Ofsted 2017), while the number of informal childminders continues to rise (Bryson et al. 2012; Simon, Owen, and Hollingworth 2015). The rapidly declining numbers of registered childminders in England has been partially blamed on the removal of childminding support workers and networks (Sure Start and NICMA 2010; Owen and Roby 2006; Ofsted 2017). However, as Mooney et al. (2001) noted on completion of a survey of former childminders in the U.K., unless there was an improvement in the pay and 
the working conditions of childminders, other policies such as start-up grants, or the development of childminding networks were unlikely to improve the retention rate of childminders. By contrast in France in 2004, the creation of a new, stable, tax-exempt employment status for independent childminders alongside childminding subsidies for parents, (OECD 2004b; Cresson, Delforge, and Lemaire 2012) has contributed to almost doubling the number of licensed childminders: from 166,700 in 1995 (Algava and Ruault 2003) to 327,775 in 2016 (Observatoire National de la Petite Enfance 2016).

\section{Implications for policy}

For policy purposes, key learning from this study involves recognising that childminding is different, fundamentally different from every other form of early years' provision, and consequently requires different policies. It is essential to recognise that the benefits and value of childminding as such, delivered at the height of its potential, as pertinent not just to children and parents, but to society as a whole (Ahnert, Pinquart, and Lamb 2006; Freeman 2011; Bronfenbrenner 2005; Tonyan, Paulsell, and Shivers 2017). A national register and national media campaigns could promote such public recognition.

Noteworthy is the emphasis in the present study on the need to develop specific childminding regulations that are appropriate and proportionate to this particular sector. Such regulations must be distinctively and precisely tailored to meet the felt needs and values of childminders, in contrast to centre-based childcare regulations, which many criticised as ill-adapted to the practical reality of childminding, similar to childminders internationally (Jones and Osgood 2007; O'Connell 2011; Fauth, Owen, and Jelicic 2013; Ang, Brooker, and Stephen 2016; Brooker 2016).

The call for accredited education specifically for childminders, at levels similar to that for all ECEC workers, could be considered a progressive step, opening up the possibility of more varied career progression (Boogaard, Bollen, and Dikkers 2013; Vandenbroeck and Bauters 2017; Vandenbroeck, Peeters, and Bouverne-De Bie 2013; Elfer and Page 2015; Oberhuemer 2011). Most European countries with regulated childminding offer specific childminding courses; however, these courses are not generally accredited, nor at the same level required for other ECEC teachers.

The value and importance of dedicated childminder support workers was clearly prioritised in the present study findings (Bromer et al. 2009; Daly 2010; DCYA Working Group 2018). Research indicates staffed networks appear to make the most impact in terms of professionalisation and improving quality (Bromer et al. 2009; Bromer and Korfmacher 2017; DCYA Working Group 2018). Internationally, such workers are in place in most regulated systems (Cook et al. 2013; Boogaard, Bollen, and Dikkers 2013; Bromer, McCabe, and Porter 2013), to provide personal support for isolated childminders, as well as improving quality standards through network training and qualifications (Bromer et al. 2009; Bromer and Korfmacher 2017; Tonyan, Paulsell, and Shivers 2017).

Childminders in this study also called for inclusion in regards to childcare subsidies for parents. However, unless the form of subsidisation contributes meaningfully to improved pay and condition for childminders (Mooney et al. 2001; Letablier and Fagnani 2009), it remains possible that the introduction of childminding regulations, accredited childminding education and dedicated support workers, could still fail to engage the majority of 
currently exempt childminders. The time has come for childminders, and other care workers, to be highly valued at more than just a rhetorical level (Lynch, Baker, and Lyons 2009).

\section{Recommendations}

These findings indicate that innovative reforms are being sought by childminders in order to sustain childminding and its innate benefits for future generations in Ireland. Further research is necessary to explore the distinctive characteristics of Irish childminding, in order to support organic development of agentic, autonomous, professional childminding sector as part of a competent ECEC system. Such a distinctive approach requires an innovative perspective on supportive regulation and inspection, on childminding subsidies and taxation as well as childminder education. As this study suggests, key features of such an approach would include a focus on a relationship-based, child-centred pedagogy alongside sensitivity to the family environment in the home.

\section{Disclosure statement}

No potential conflict of interest was reported by the author.

\section{Funding}

This research is funded by the Irish Research Council with Childminding Ireland as enterprise partner. Grant number: EPSPG/2016/150.

\section{ORCID}

Miriam O'regan (D) http://orcid.org/0000-0001-9272-5815

\section{References}

Acts of the Oireachtas. 2012. "National Vetting Bureau (Children and Vulnerable Persons) Act," no. 47: 1-33. http://www.irishstatutebook.ie/pdf/2012/en.act.2012.0047.pdf.

Ahnert, L., M. Pinquart, and M. E. Lamb. 2006. “Security of Children's Relationships With Nonparental Care Providers.” Child Development 74 (3): 664-679. doi:10.1111/j.1467-8624.2006.00896.x.

Algava, Élisabeth, and Marie Ruault. 2003. "Les Assistantes Maternelles: Une Profession En Développement." http://drees.solidarites-sante.gouv.fr/IMG/pdf/er232.pdf.

Ang, Lynn, Elizabeth Brooker, and Christine Stephen. 2016. "A Review of the Research on Childminding: Understanding Children's Experiences in Home-Based Childcare Settings.” Early Childhood Education Journal 45 (2): 1-10. doi:10.1007/s10643-016-0773-2.

Baker, John, and Kathleen Lynch. 2012. "Inequalities of Love and Care and Their Theoretical Implications." Social Justice Series 12 (1): 1-22.

Baltar, F., and I. Brunet. 2012. "Social Research 2.0: Virtual Snowball Sampling Method Using Facebook.” Internet Research 22 (1): 57-74. doi:10.1108/10662241211199960.

Bauters, Valerie, and Michel Vandenbroeck. 2017. "Bauters \& Vandenbroeck The Professionalisation of Family Day Care in Flanders France and Germany." European Early Childhood Education Research Journal. doi:10.1080/1350293X.2017.1308164.

Bhutta, C. B. 2012. "Not by the Book: Facebook as a Sampling Frame." Sociological Methods and Research 41 (1): 57-88. doi:10.1177/0049124112440795. 
Bond, M., and D. Kersey. 2001. "Expanding Childminding Provision in Areas of Deprivation." Local Economy 17 (4): 303-312. doi:10.1080/0269094022000019826.

Boogaard, M., I. Bollen, and L. Dikkers. 2013. Gastouderopvang in West-Europese Landen. www. kohnstamminstituut.uva.nl.

Brannen, Julia, and Peter Moss. 2003. Rethinking Children's Care. Open University Press. http:// eprints.ioe.ac.uk/3029/.

Brock, Avril. 2013. "Building a Model of Early Years Professionalism from Practitioners' Perspectives." Journal of Early Childhood Research 11 (1): 27-44. doi:10.1177/1476718X12456003.

Bromer, J., M., Van Haitsma, K., Daley, and K., Modigliani 2009. Staffed Support Networks and Quality in Family Child Care: Findings from The Family Child Care Network Impact Study. Accessed November 1, 2017.http://www.erikson.edu/wp-content/uploads/Full_report_web1.pdf.

Bromer, J., and J. Korfmacher. 2017. "Providing High-Quality Support Services to Home-Based Child Care: A Conceptual Model and Literature Review." Early Education and Development 28 (6): 745-772. doi:10.1080/10409289.2016.1256720.

Bromer, J., L. A. Mccabe, and T. Porter. 2013. "Special Section on Understanding and Improving Quality in Family Child Care: Introduction and Commentary." Early Childhood Research Quarterly 28 (4): 875-878. doi:10.1016/j.ecresq.2013.08.003.

Bronfenbrenner, U. 2005. Making Human Beings Human: Bioecological Perspectives on Human Development. Thousand Oaks, CA: Sage Publications.

Brooker, Liz. 2016. "Childminders, Parents and Policy: Testing the Triangle of Care." Journal of Early Childhood Research 14: 69-83. doi:10.1177/1476718X14548779.

Brown, Juanita, Ken Homer, and D. Isaacs. 2007. “The World Café.” In The Change Handbook, 179-194. San Francisco: Berrett Koehler.

Brown, J., and D. Isaacs. 2007. The World Café Community (2005) The World Café, Shaping Our Future Through Conversations That Matter. San Francisco, CA: Bernett-Koehler.

Bryman, Alan. 2016. Social Research Methods. doi:10.4135/9781849209939.

Bryson, Caroline, Mike Brewer, Luke Sibieta, and Sarah Butt. 2012. "The Role of Informal Childcare.” https://www.nuffieldfoundation.org/sites/default/files/files/The_role_of_informal_ childcare_FULL_REPORT.pdf.

Campbell-Barr, Verity. 2018. "The Silencing of the Knowledge-Base in Early Childhood Education and Care Professionalism." International Journal of Early Years Education, doi:10.1080/ 09669760.2017.1414689.

CECDE. 2006. "Síolta, The National Quality Framework for Early Childhood Education," no. April: $1-19$.

Central Statistics Office. 2017a. “Census 2016 Summary Results.” http://www.cso.ie/en/aboutus/ copyrightpolicy/.

Central Statistics Office. 2017b. "CSO Quarterly National Household Survey Module on Childcare2017."

Cook, K., Davis, E., Williamson, L., Harrison, L. J., and Sims, M. 2013. “Discourses of professionalism in family day care.” Contemporary Issues in Early Childhood 14 (2): 112-126. doi:10.2304/ ciec.2013.14.2.112.

Cooperrider, D., and S. Srivastva. 1987. “Appreciative Inquiry in Organizational Life.” Research in Organisational Change and Development 1: 129-169.

Corrigan, Carmel. 2000. "OECD Thematic Review of Background Report." OECD. http://www. oecd.org/ireland/34431749.pdf.

Cresson, Geneviève, Sandie Delforge, and Dominique Lemaire. 2012. "La "qualité » Du Travail Dans Le Métier d'assistante Maternelle. Le Point de Vue Des «régulateurs » de Ce Métier." Politiques Sociales et Familiales 109 (1): 79-86. doi:10.3406/caf.2012.2887.

Creswell, John W. 2009. "Research Design Qualitative, Quantitative, and Mixed Methods Approaches." http://www.ceil-conicet.gov.ar/wp-content/uploads/2015/10/Creswell-Cap-10.pdf.

Dalli, Carmen, Linda Miller, and Mathias Urban. 2012. "Early Childhood Grows up: Towards a Critical Ecology of the Profession: Setting the Scene." Early Childhood Grows Up: Towards a Critical Ecology of the Profession, 3-19. doi:10.1007/978-94-007-2718-2_1. 
Daly, Mary. 2010. "An Evaluation of the Impact of the National Childminding Initiative on the Quality of Childminding in Waterford City and County." Waterford City \& County Childcare Committees, and Health Service Executive South.

Davis, Elise, Naomi Priest, Belinda Davies, Lisa Smyth, Elizabeth Waters, Helen Herrman, Margaret Sims, et al. 2012. "Family Day Care Educators: An Exploration of Their Understanding and Experiences Promoting Children's Social and Emotional Wellbeing." Early Child Development and Care 182 (9): 1193-1208. doi:10.1080/03004430.2011.603420.

DCYA. 2008. "National Guidelines for Childminders." http://www.dcya.gov.ie/viewdoc.asp?fn=/ documents/Publications/National_Guidelines_for_Childminders_Revised_August_2008.pdf.

DCYA. 2013. "Right from the Start: Report of the Expert Advisory Group on the Early Years Strategy," no. September: 137. http://www.dcya.gov.ie/documents/policy/RightFromTheStart.pdf.

DCYA. 2016. Child Care Act 1991 (Early Years Services) Regulations 2016. Vol. 1991. Department of Children and Youth Affairs.

DCYA. 2017. “Action Plan on School Age Childcare." https://www.education.ie/en/Publications/ Education-Reports/Action-Plan-On-School-Age-Childcare.pdf.

DCYA Working Group. 2018. "Pathway to a Quality Support \& Assurance System for Childminding: Summary Report of the Working Group on Reforms and Supports for the Childminding Sector."

Denscombe, Martyn. 2009. "Item Non-Response Rates: A Comparison of Online and Paper Questionnaires.” International Journal of Social Research Methodology 12 (4): 281-291. doi:10. 1080/13645570802054706.

Denscombe, Martyn. 2014. The Good Research Guide: For Small-Scale Social Research Projects. Maidenhead: Open University Press.

Department of Children \& Youth Affairs. 2016. "Policy Paper on the Development of a New Single Affordable Childcare Scheme.” https://www.dcya.gov.ie/documents/earlyyears/20161028Policy Paper.pdf.

DJELR. 2000. "National Childcare Strategy.” http://www.justice.ie/en/JELR/Childcare1.pdf/Files/ Childcare1.pdf.

Dyer, Mary A. 2018. "Being a Professional or Practising Professionally." European Early Childhood Education Research Journal 26 (3): 347-361. doi:10.1080/1350293X.2018.1462999.

Elfer, P., and J. Page. 2015. “Pedagogy with Babies: Perspectives of Eight Nursery Managers.” Early Child Development and Care. Taylor \& Francis 185 (11-12): 1762-1782. doi:10.1080/03004430. 2015.1028399.

Fagnani, Jeanne, and Antoine Math. 2012. "Des Assistantes Maternelles Mieux Formées et Plus Qualifiées. Les Parents Consentiraient-Ils à Augmenter La Rémunération ?” Politiques Sociales et Familiales 109 (1): 59-73. doi:10.3406/caf.2012.2884.

Fauth, Rebecca, Helena Jelicic, Johanna Leo, Natasha Wilmott, and Sue Owen. 2011. "Childminding Practice in England, Final Report," no. 258825: 141.

Fauth, Rebecca, Sue Owen, and Helena Jelicic. 2013. "The Next Best Thing to Being at Home: Parents' Views of Quality in Home-Based Childcare Settings," no. February.

Feeley, Niamh. 2012. "Report on Survey of Registered Members of Childminding Ireland." doi:10.1080/00050350.1998.10558755.

Fetters, Michael D, Leslie A Curry, and John W Creswell. 2013. "Achieving Integration in Mixed Methods Designs - Principles and Practices.” Health Services Research 48 (6 PART2): 21342156. doi:10.1111/1475-6773.12117.

Freeman, R. 2011. "Home, School Partnerships in Family Child Care: Providers' Relationships within Their Communities." Early Child Development and Care 181 (6): 827-845. doi:10. 1080/03004430.2010.491704.

Gallagher, Aisling. 2012. "Neoliberal Governmentality and the Respatialisation of Childcare in Ireland." Geoforum; Journal of Physical, Human, and Regional Geosciences 43 (3): 464-471. doi:10.1016/j.geoforum.2011.10.004.

Garrity, Sheila, and Brian McGrath. 2011. “It's Not Like a Job Now; It's Part of Me': Exploring African Women's Experiences in the Irish Childcare Sector." Child Care in Practice 17 (1): 69-86. doi:10.1080/13575279.2010.522977. 
Goodbody Economic Consultants. 2011. “Children 2020 : Cost-Benefit Analysis,” no. November.

Govt. of Ireland. 2019. "A Whole-of-Government Strategy for Babies, Young Children and Their Families.” https://www.dcya.gov.ie/documents/earlyyears/19112018_4966_DCYA_EarlyYears_ Booklet_A4_v22_WEB.pdf.

Hargreaves, Andy. 2000. "Four Ages of Professionalism and Professional Learning." Teachers and Teaching: Theory and Practice 6 (2): 151-182. doi:10.1080/713698714.

Hayes, Noirin, and Siobhan Bradley. 2009. "Right by Children : Children 's Rights and Rights Based Approaches to Policy Making in Early Childhood Education and Care : The Case of Ireland The Case of Ireland."

Hayes, Noirin, and Carole Newman. 2005. "An Accessible Childcare Model.”

Heckathorn, Douglas D. 1997. "Respondent Driven Sampling: A New Approach to the Study of Hidden Populations." Social Problems 2 (May): 174-199.

Higgins, K. 1998. "Researching Hidden Populations.” In Making Research Work: Promoting Child Care Policy and Practice, edited by D. Iwaniec and J. Pinkerton, 141-162. Chichester: Wiley.

Jones, Liz, and Jayne Osgood. 2007. "Mapping the Fabricated Identity of Childminders: Pride and Prejudice." Contemporary Issues in Early Childhood 8 (4): 289-300. doi:10.2304/ciec.2007.8.4.289.

Karlsson, Malene. 1995. Family Day Care in Europe. Brussels: European Commission.

Kontos, Susan. 1994. “The Ecology of Family Day Care.” Early Childhood Research Quarterly 9 (1): 87-110. doi:10.1016/0885-2006(94)90030-2.

Laevers, Ferre, Evelien Buyse, Mieke Daems, and Bart Declercq. 2016. "Welbevinden En Betrokkenheid Als Toetsstenen Voor Kwaliteit in de Kinderopvang. Implicaties Voor Het Monitoren van Kwaliteit.” BKK. https://lirias.kuleuven.be/handle/123456789/572800.

Letablier, Marie-Thérèse, and Jeanne Fagnani. 2009. "European Alliance for Families European Expert Group on Demography Best Practice Meeting on Child Care by Child Minders in France Childminders in the French Childcare Policy."

aLightfoot, Sarah, and David Frost. 2015. "The Professional Identity of Early Years Educators in England: Implications for a Transformative Approach to Continuing Professional Development." Professional Development in Education 41 (2): 401-418. doi:10.1080/19415257.2014.989256.

Lloyd, Eva, and Helen Penn. 2012. Childcare Markets : Can They Deliver an Equitable Service?. Bristol: Policy Press.

Lumsden, Eunice. 2010. “The New Early Years Professional in England.” International Journal for Cross-Disciplinary Subjects in Education 1 (3): 173-181.

Lynch, Kathleen, John Baker, and Maureen Lyons. 2009. “Affective Equality: Love, Care and Injustice.” https://caringlabor.files.wordpress.com/2010/09/affectiveequality.pdf.

Malthus, Caroline. 2017. "The Good Research Guide: For Small-Scale Social Research Projects." Higher Education Research \& Development 36 (4): 872-874. doi:10.1080/07294360.2017.1281284.

McGinnity, Frances, Helen Russell, and Aisling Murray. 2015. "Growing Up in Ireland Non-parental Childcare and Child Cognitive Outcomes at Age 5: Results from the Growing Up in Ireland Infant Cohort." www.dcya.gov.ie.

Melhuish, Edward. 2016. Provision of Quality Early Childcare Services. Luxembourg: Publication Office of the European Union.

Melhuish, Edward, Julian Gardiner, and Stephen Morris. 2017. "Study of Early Education and Development (SEED): Impact Study on Early Education Use and Child Outcomes up to Age Three." https://e-space.mmu.ac.uk/618814/1/Study of Early Education and Development (SEED)- Impact Study on Early Education Use and Child Outcomes up to Age Three Research report.pdf.

Moloney, Mary. 2010. "Unreasonable Expectations: The Dilemma for Pedagogues in Delivering Policy Objectives." European Early Childhood Education Research Journal 18 (2): 181-198. doi:10.1080/13502931003784362.

Moloney, Mary. 2016. “The Affordable Childcare Scheme: Parental Panacea, or Pedagogical Paradox," no. November.

Mooney, Ann, Peter Moss, Charlie Owen, Ann Mooney, Peter Moss, and Charlie Owen. 2001. “A Survey of Former Childminders." http://dera.ioe.ac.uk/4652/1/RR300.pdf. 
Mooney, A., and J. Statham. 2003. Family Day Care: International Perspectives on Policy, Practice and Quality. Edited by Ann Mooney and June Statham.

Musatti, T., M. Picchio, and S. Mayer. 2016. "Continuous Professional Support and Quality: The Case of Pistoia." In Pathways To, edited by M. Vandenbroeck, M. Urban \& J. Peeters.

NCCA. 2009. "Childhood Curriculum Framework: Partnership in Action." An Leanbh Óg, The OMEP Ireland Journal of Early Childhood 3 (1): 1-24. http://www.ncca.ie/en/Curriculum_ and_Assessment/Early_Childhood_and_Primary_Education.

Neylon, G. 2014. "An Analysis of Irish Pre-school Practice and Pedagogy Using the Early Childhood Environmental Four Curricular Subscales.” Irish Educational Studies 33 (1): 99116. doi:10.1080/03323315.2014.888237.

Nutbrown, Cathy. 2012. "Foundations for Quality The Independent Review of Early Education and Childcare Qualifications Final Report Nutbrown Review Nutbrown Review.” doi:DFE-00068-2012.

Oberhuemer, P. 2011. "The Early Childhood Education Workforce in Europe Between Divergencies and Emergencies." International Journal of Child Care and Education Policy Education 5 (1): 55-63. doi:10.1007/2288-6729-5-1-55.

Observatoire National de la Petite Enfance. 2016. "Résultats Du Rapport 2016 de l'Observatoire National de La Petite Enfance La."

O'Connell, Rebecca. 2008. "The Meaning of Home-Based Childcare in an Era of Quality: Childminding in an Inner London Borough and the Encounter with Professionalisation."

O'Connell, Rebecca. 2011. "Paperwork, Rotas, Words and Posters: An Anthropological Account of Some Inner London Childminders' Encounters with Professionalisation.” Sociological Review 59 (4): 779-802. doi:10.1111/j.1467-954X.2011.02034.X.

OECD. 2004a, April. "Early Childhood Education and Care Policy. Country Note for Ireland," pp. 1-108.

OECD. 2004b. "Early Childhood Education and Care Policy in France." OECD Country Note, doi:10.1016/j.socscimed.2011.12.010.

OECD. 2006. Starting Strong II. OECD Publishing. doi:10.1007/s13398-014-0173-7.2.

Ofsted. 2017. "Childcare Providers and Inspections."

Ortlipp, Michelle, Leonie Arthur, and Christine Woodrow. 2011. "Discourses of the Early Years Learning Framework: Constructing the Early Childhood Professional." Contemporary Issues in Early Childhood 12 (1), doi:10.2304/ciec.2011.12.1.56.

Osgood, J. 2004. "Time to Get Down to Business?: The Responses of Early Years Practitioners to Entrepreneurial Approaches to Professionalism." Journal of Early Childhood Research 2 (1): 5-24. doi:10.1177/1476718X0421001.

Osgood, Jayne. 2006. "Deconstructing Professionalism in Early Childhood Education: Resisting the Regulatory Gaze." Contemporary Issues in Early Childhood 7 (1): 5-14. doi:10.2304/ciec.2006.7.1.5.

Osgood, Jayne. 2010. "Reconstructing Professionalism in ECEC: The Case for the 'Critically Reflective Emotional Professional.” Early Years 30 (2): 119-133. doi:10.1080/09575146.2010.490905.

Otero, Maria Pia, and Edward Melhuish. 2015. "Study of Early Education and Development (SEED): Study of the Quality of Childminder Provision in England," no. September: 1-62.

Owen, S., and P. Roby. 2006. Organised Systems of Childminding in Britain: A Sociological Examination of Changing Social Policies, a Profession and the Operation of a Service. Accessed April 11, 2017. http://elibrary.ru/item.asp?id=9412308.

Page, Jools. 2011. “Do Mothers Want Professional Carers to Love Their Babies?” Journal of Early Childhood Research 9 (3): 310-323. doi:10.1177/1476718X11407980.

Peeters, Jan, Mathias Urban, and Michel Vandenbroeck. 2016. "Lessons Learnt and a Debate to Be Continued." In Pathways to Professionalism in Early Childhood Education and Care, 132-136. doi:10.4324/9781315688190.

Peeters, J., and M. Vandenbroeck. 2011. "Childcare Practitioners and the Process of Professionalization." In Professionalization, Leadership and Management in the Early Years, 62-74. doi:10.4135/9781446288795.n5.

Plantenga, Janneke, Chantal Remery, Melissa Siegel, and Loredana Sementini. 2008. "Childcare Services in 25 European Union Member States: The Barcelona Targets Revisited." Comparative Social Research, doi:10.1016/S0195-6310(07)00001-4. 
Porter, T., J. Bromer, and S. Moodie. 2011. Quality Rating and Improvement Systems (QRIS) and Family-Sensitive Care Giving in Early Care and Education Arrangements: Promising Directions and Challenges. Research-to-Policy, Research-to-Practice Brief OPRE 2011-11d, (October).

Russell, Helen, Oona Kenny, and Frances McGinnity. 2016. "Childcare, Early Education and SocioEmotional Outcomes At Age 5 Evidence from the Growing Up in Ireland Study."

The Scottish Government. 2017. Health and Social Care Standards: My Support, My Life, pp. 1-18. http://www.gov.scot/Resource/0052/00520693.pdf.

Shannon, Rachel, Teresa Geraghty, and Frances Molyneaux. 2014. "Childminding in Northern Ireland: An Exploration of Practice, Quality and the Impact of Vertical Placements on Children." NCB Northern Ireland.

Simon, Antonia, Charlie Owen, and Katie Hollingworth. 2015. "Provision and Use of Preschool Childcare in Britain Institute of Education," no. July.

Start Strong. 2012. "Childminding : Regulation and Recognition," no. October: 1-4.

Steier, Frederick, Juanita Brown, and Flavio Mesquita da Silva. 2015. "The World Café in Action Research Settings.” In The SAGE Handbook of Action Research, edited by Hilary Bradbury, 3rd ed., 1315. Sage. https://books.google.pl/books?id=OA50CQAAQBAJ.

Sure Start and NICMA. 2010. The Role of Childminding Networks in Supporting the Sure Start Programme in Northern Ireland. Accessed September 25, 2017. https://nicma.org/getmedia/ c82f419b-e3eb-4499-9d41-ddf6a3f1da63/ChildmindingNetworksEvaluationExec-Sum.aspx.

Survey Monkey. 2009. “Tips to Enhance Survey Respondent Participation.” Response Rates \& Surveying Techniques, 1-3. http://s3.amazonaws.com/SurveyMonkeyFiles/Response_Rates.pdf.

Tonyan, Holli A. 2012. "Understanding Home-Based Care as a Culturally Organized Ecological Niche: Cultural Models and the Organization of Daily Routines". A poster presented April 20, 2013, at the Biennial Meeting of the Society for Research in Child Development, Seattle, Washington DC. doi:10.13140/2.1.1468.5120.

Tonyan, Holli A. 2015. "Everyday Routines: A Window Into the Cultural Organization of Family Child Care." Journal of Early Childhood Research 13 (3): 311-327. doi:10.1177/ $1476718 X 14523748$.

Tonyan, Holli A. 2017. "Opportunities to Practice What Is Locally Valued: An Ecocultural Perspective on Quality in Family Child Care.” Early Education and Development, doi:10.1080/ 10409289.2017.1303304.

Tonyan, Holli A, and Joce Nuttall. 2014. "Connecting Cultural Models of Home-Based Care and Childminders' Career Paths: An Eco-Cultural Analysis.” International Journal of Early Years Education 22 (1): 117-138. doi:10.1080/09669760.2013.809654.

Tonyan, Holli A., Diane Paulsell, and Eva Marie Shivers. 2017. "Understanding and Incorporating Home-Based Child Care Into Early Education and Development Systems." Early Education and Development 28 (6): 633-639.

Urban, Mathias, Michel Vandenbroek, Arianna Lazzari, Jan Peeters, and Katrien van Laere. 2011. "Competence Requirements in Early Childhood Education and Care (CoRe)."

Vandenbroeck, Michel, and Valerie Bauters. 2017. "Family Day Care: The Trillema of Professionalisation, Sustainability and Fairness in Flanders, France and Germany." In UnderThree Year Olds in Policy and Practice, 1-17. doi:10.1007/978-981-10-2275-3.

Vandenbroeck, M., J. Peeters, and M. Bouverne-De Bie. 2013. "Lifelong Learning and the Counter/ Professionalisation of Childcare: A Case Study of Local Hybridizations of Global European Discourses." European Early Childhood Education Research Journal 21 (1): 109-124. doi:10. 1080/1350293X.2012.760339.

Wolfe, Toby, Bernie O’Donoghue-Hynes, and Nóirín Hayes. 2013. “Rapid Change Without Transformation: The Dominance of a National Policy Paradigm Over International Influences on ECEC Development in Ireland 1995-2012." International Journal of Early Childhood 45 (2): 191-205. doi:10.1007/s13158-013-0090-5.

The World Café Community Foundation. 2015. "Cafe to Go: A Quick Reference Guide for Hosting World Cafe," 10. www.theworldcafe.com. 